Document downloaded from:

http://hdl.handle.net/10251/147781

This paper must be cited as:

Manzo, E.; Ciavatta, ML.; López-Gresa, MP.; Gavagnin, M.; Villani, G.; Naik, CG.; Cimino, G. (2007). New bioactive hydrogenated linderazulene-derivatives from the gorgonian Echinogorgia complexa. Tetrahedron Letters. 48(14):2569-2571. https://doi.org/10.1016/j.tetlet.2007.02.020

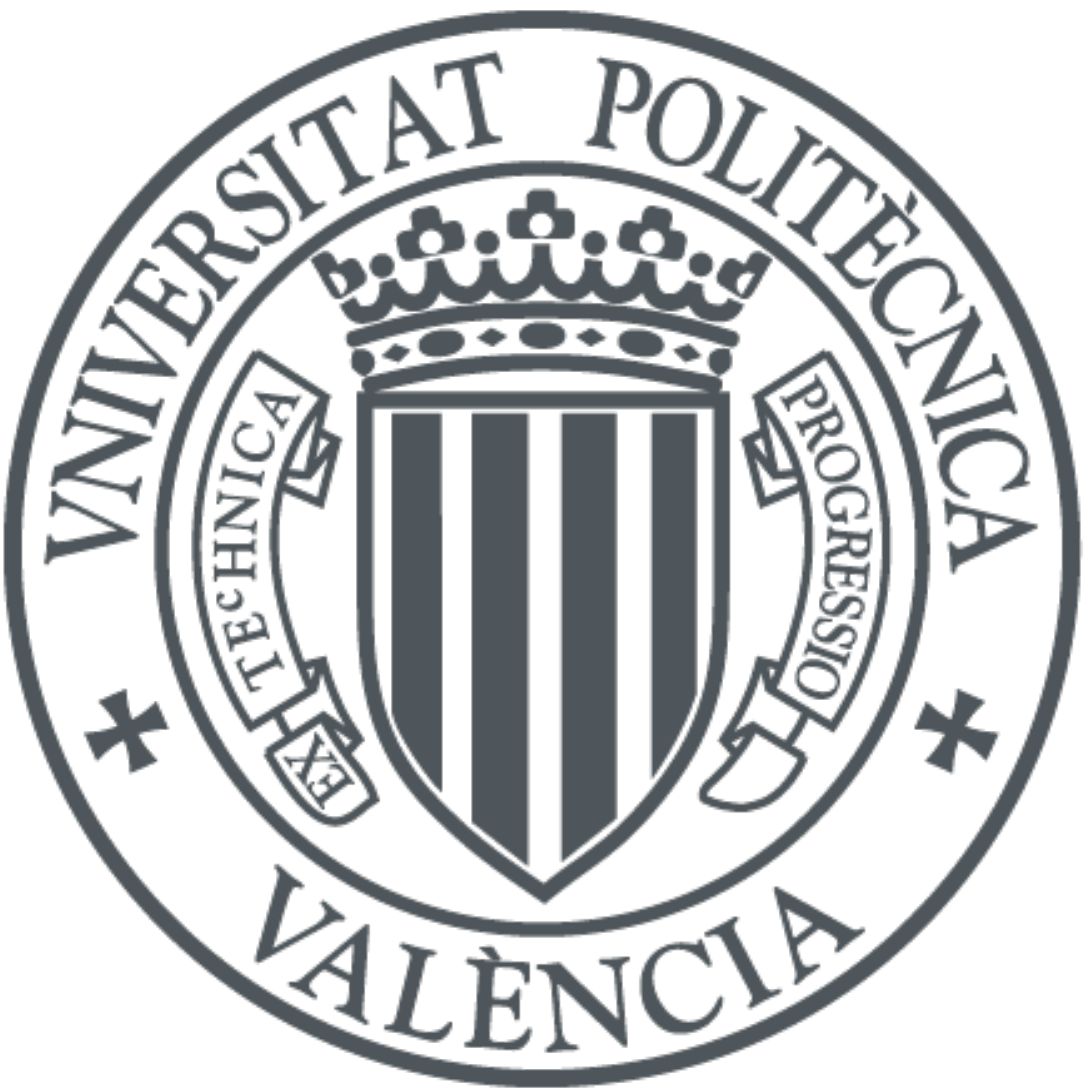

The final publication is available at

https://doi.org/10.1016/j.tetlet.2007.02.020

Copyright Elsevier

Additional Information 
New Bioactive Hydrogenated Linderazulene-Derivatives from the Gorgonian Echinogorgia complexa

Emiliano Manzo,* Maria Letizia Ciavatta, Maria Pilar Lopez Gresa, Margherita Gavagnin, Guido Villani, Chandrakant Govind Naik and Guido Cimino

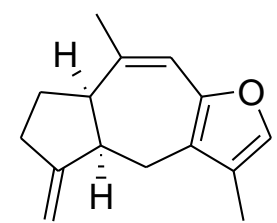

3

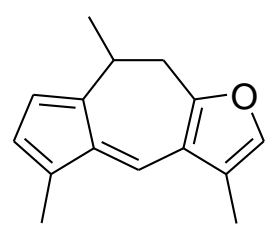

4

Iso-echinofuran (3) and 8,9-dihydro-linderazulene (4) are inhibitors of mitochondrial respiratory chain. 


\title{
New Bioactive Hydrogenated Linderazulene-Derivatives from the Gorgonian Echinogorgia complexa
}

\author{
Emiliano Manzo, ${ }^{\mathrm{a}^{*}}$ Maria Letizia Ciavatta, ${ }^{\mathrm{a}}$ Maria Pilar Lopez Gresa, ${ }^{\mathrm{b}}$ Margherita Gavagnin, ${ }^{\mathrm{a}}$ \\ Guido Villani, ${ }^{a}$ Chandrakant Govind Naik ${ }^{\mathrm{c}}$ and Guido Cimino ${ }^{\mathrm{a}}$ \\ a Istituto di Chimica Biomolecolare, CNR, Via Campi Flegrei 34, I 80078-Pozzuoli (Naples), Italy \\ ${ }^{\mathrm{b}}$ Centro Ecologia Quimica Agricola, Universidad Politecnica Valencia, Campus de Vera, Valencia, Spain \\ ${ }^{\mathrm{c}}$ National Institute of Oceanography, CSIR, Dona Paula, 403004 Goa, India
}

\begin{abstract}
Chemical analysis of the secondary metabolite pattern of the gorgonian Echinogorgia complexa, collected along South Indian coasts, showed the presence of two new tricyclic guaiane furanosesquiterpenes $\mathbf{3}$ and $\mathbf{4}$ co-occurring with the known echinofuran $\mathbf{5}$, which are structurally related to the pigment linderazulene $\mathbf{1}$. The unprecedented molecules 3 and 4 were characterized by spectral methods, mainly by NMR techniques. Compounds 3-5 displayed moderate activity in the mitochondrial respiratory chain inhibition assay.
\end{abstract}

Keywords: gorgonian, pigments, linderazulene, echinofuran, furanosesquiterpenes, MRC.

*Author to whom correspondence should be addressed; E-mail: emanzo@icmib.na.cnr.it

Azulene sesquiterpenes are typical secondary metabolites of marine octocorals of the order Gorgonacea.$^{1-11}$ Most of them are responsible of the brilliant colors of gorgonians and in addition various bioactivities including cytotoxic, antimicrobial, antifungal, immunostimulatory and cell division inhibitory properties have been reported for azulene sesquiterpenes. ${ }^{7,8,10}$ The two members of this class that have been isolated from marine organisms are linderazulene $(\mathbf{1})^{1,3,5}$ and guaiazulene (2),,$^{2,3,10,12}$ previously reported from terrestrial sources. ${ }^{13,14}$ Subsequently, several related sesquiterpenes have been found in gorgonian species belonging to different genera (Paramuricea, Acalycigorgia, Bebryce, Echinogorgia, Pseudopterogorgia). ${ }^{3-11,15,16}$ Guaiane azulenes have been found to be quite labile and easily decomposable on exposure to air and light during the work-up. A photo artifact from linderazulene (1) has been also reported. ${ }^{17}$

In this paper we describe the isolation, structure elucidation and biological activity of two new hydrogenated linderazulene derivatives designated as tricyclic furanosesquiterpenes $\mathbf{3}$ and $\mathbf{4}$, co-occurring with the known echinofuran $\mathbf{5}^{8}$ in the gorgonian Echinogorgia complexa Nutting collected from subtidal regions of West Indian coasts (Goa).

Although previous studies on E. complexa showed a strong antifouling activity of the alcoholic extract prepared from this species, ${ }^{18,19}$ but no active compounds were reported so far.

INSERT FORMULAE 1-6

A sample of the gorgonian E. complexa (dry weight $54 \mathrm{~g}$ ) was collected in December 2005, immediately frozen at $-20{ }^{\circ} \mathrm{C}$ and subsequently transferred to ICB for the chemical studies. The frozen animal was extracted exhaustively with acetone $(4 \times 200 \mathrm{~mL})$. The $\mathrm{Et}_{2} \mathrm{O}$ soluble 
fraction of the acetone extract was concentrated under reduced pressure to furnish a residual orange oil (600 mg), which was analyzed by TLC chromatography (light petroleum ether/diethyl ether in different ratio) showing mainly the presence of sterols and lipids. The less polar part of the extract was found to contain three yellow spots between Rf 0.35-0.55 ( $n$ hexane). The extract was then purified on a silica-gel column (petroleum light ether with increasing amount of diethyl ether) to obtain the mixture of yellow components $(18 \mathrm{mg})$. A preliminary NMR analysis of this mixture suggested the presence of furano-sesquiterpenes, and subsequent comparison with available literature data indicated that these three compounds were related to linderazulene type of structural framework. This fraction was further purified on a semi-preparative silica-gel plate, using $n$-hexane as eluent, to afford echinofuran $(\mathbf{5}, 1.0$ $\mathrm{mg})$ and two novel compounds named as iso-echinofuran $(3,0.7 \mathrm{mg})$ and 8,9-dihydrolinderazulene $(4,0.7 \mathrm{mg})$ in order of increasing polarity.

(-)-Echinofuran (5) was identified by comparison of ${ }^{1} \mathrm{H}-\mathrm{NMR}$, mass spectral data and $[\alpha]^{25} \mathrm{D}$ with the literature values. ${ }^{8,20}$ The ${ }^{13} \mathrm{C}-\mathrm{NMR}$ values of $\mathbf{5}$, not previously assigned, were also assigned by performing 2D-NMR experiments. ${ }^{21}$ Due to high susceptibility of these molecules in chloroform, NMR analysis of $\mathbf{5}$ was carried out in deuterated benzene. Compounds 3 and $\mathbf{4}$, structurally related to $\mathbf{5}$, were also analyzed in the same manner.

Compound $3^{22}$ had a molecular formula $\mathrm{C}_{15} \mathrm{H}_{18} \mathrm{O}$, which was determined by HR-APCIMS giving a pseudo-molecular ion $[\mathrm{M}+\mathrm{H}]^{+} \mathrm{m} / z$ 215.1431, and ${ }^{13} \mathrm{C}-\mathrm{NMR}$ spectrum (Table 1). The ${ }^{1} \mathrm{H}-\mathrm{NMR}$ spectrum of $\mathbf{3}$ showed strong analogies with that of echinofuran (5), differing only from this are the presence of two additional signals, an aliphatic methine proton $(\delta 2.35, \mathrm{~m}$, $\mathrm{H}-7 \mathrm{a})$ and an olefinic proton $(\delta 6.33$, bs, $\mathrm{H}-9)$, which replaced the methylene group $\mathrm{H}_{2}-9$ resonating at $\delta 3.59(1 \mathrm{H}, \mathrm{bd}, J=17.8 \mathrm{~Hz}, \mathrm{H}-9)$ and $3.02(1 \mathrm{H}, \mathrm{d}, J=17.8 \mathrm{~Hz}, \mathrm{H}-9)$ in $\mathbf{5}$. The ${ }^{13} \mathrm{C}-$ NMR spectrum showed signals attributable to seven $\mathrm{sp}^{3}$ carbons (two vinyl methyls at $\delta 7.8$ and $\delta$ 22.2; three methylenes at $\delta$ 28.6, 29.8 and 32.0; two methine carbons at $\delta 50.9$ and 45.9) and eight $\mathrm{sp}^{2}$ carbons attributable to four double bonds: two tri-substituted $(\delta 136.0,121.8$, 137.3 and 116.8), a tetra-substituted ( $\delta 149.0$ and 120.0), and an exocyclic double bond $(\delta$ 105.6 and 156.1). These data indicated that compound $\mathbf{3}$ was an isomer of $\mathbf{5}$, with a double bond at C-8/C-9 position instead of a double bond at C-7a/C-8. The relative stereochemistry of A,B-ring junction of $\mathbf{3}$ was suggested to be cis, the same as the related bebryazulene (6) by comparing the carbon values of 5 -membered ring of both compounds, ${ }^{11}$ that were similar. Unfortunately, 3 degraded before recording nOe difference experiments, which had been planned to confirm this suggestion. The proton and carbon values of $\mathbf{3}$ were assigned by 2DNMR experiments (Table 1).

\section{INSERT TABLE 1}

The molecular formula $\mathrm{C}_{15} \mathrm{H}_{16} \mathrm{O}$ of compound $\mathbf{4}^{23}$ was determined by HR-APCIMS which gave a pseudo-molecular ion $[\mathrm{M}+\mathrm{H}]^{+} \mathrm{m} / z 213.1520$ and ${ }^{13} \mathrm{C}-\mathrm{NMR}$ values (Table 1 ). The ${ }^{1} \mathrm{H}-$ NMR spectrum displayed olefinic signals at $\delta 6.75(1 \mathrm{H}, \mathrm{s}, \mathrm{H}-4)$ and $6.02(2 \mathrm{H}, \mathrm{bs}, \mathrm{H}-6$ and $\mathrm{H}-$ 7), a singlet at $\delta 6.77$ due an $\alpha$-furan proton (H-2), two double doublets at $\delta 2.82(1 \mathrm{H}$, dd, $J=16.4,2.9 \mathrm{~Hz}, \mathrm{H}-9)$ and $2.66(1 \mathrm{H}, \mathrm{dd}, J=16.4,9.4 \mathrm{~Hz}, \mathrm{H}-9)$ attributed to a methylene coupled 
to a methine at $\delta 2.83(1 \mathrm{H}, \mathrm{m}, \mathrm{H}-8)$, which was further correlated to a secondary methyl signal resonating at $\delta 1.08\left(3 \mathrm{H}, \mathrm{d}, J=6.8 \mathrm{~Hz}, \mathrm{H}_{3}-12\right)$, and finally two methyl broad singlets occurring at $\delta 1.73\left(\mathrm{H}_{3}-10\right)$ and $2.06\left(\mathrm{H}_{3}-11\right)$. The ${ }^{13} \mathrm{C}-\mathrm{NMR}$ spectrum contained signals due to ten $\mathrm{sp}^{2}$ carbons according to the presence of an additional unsaturation with respect to compound 3 (Table 1). Careful comparison of spectral data of $\mathbf{4}$ with those of linderazulene-related compounds ${ }^{1,5,7,8,11}$ suggested that it was a dihydro-linderazulene. A series of 2D-NMR experiments $\left({ }^{1} \mathrm{H}-{ }^{1} \mathrm{H}\right.$ COSY, HMQC, HMBC) led to the assignment of structure 4 and fully satisfying with assigned values of proton and carbon signals (Table 1).

Interesting biological activities have been reported in the literature for several guaianoid azulene metabolites. ${ }^{7,8,10}$ In particular, echinofuran (5) was found to inhibit cell division of fertilized sea urchin eggs. ${ }^{8}$ Compounds 3-5, isolated in the present study, have been tested in the mitochondrial respiratory chain assay. They displayed a moderate activity for the inhibition of the integrated electron transfer chain (NADH oxidase activity) in beef heart submitochondrial particles (SMP). ${ }^{24} \mathrm{IC}_{50}$ values were $4.3 \pm 0.15 \mu \mathrm{M}, 2.5 \pm 0.04 \mu \mathrm{M}$ and $2.2 \pm$ $0.31 \mu \mathrm{M}$ for compounds $\mathbf{3}, \mathbf{4}$ and 5 respectively, whereas full inhibition of rotenone sensitive NADH oxidase activity was achieved at approximately $2 \mu \mathrm{M} .{ }^{25}$

\section{Acknowledgements}

We thank ICB Mass Service and ICB NMR Service Centre (Mr. S. Zambardino is kindly acknowledged), Mr. C. Iodice for spectrophotometric measurements and Mr. R. Turco for graphical work. Biological assays were performed by Prof. Estornell D. and Dr. Romero V. that the authors kindly acknowledge.This work was partially supported by a bilateral CNR(Italy)-CSIR(India) programme. We are grateful to Dr. P.A.Thomas (Central Marine Fisheries Research InstituteCMFRI, Vizhijam, Kerala, India) for the identification of E.complexa.

\section{References and notes}

1. Imre, S.; Thomson, R.H.; Yalhi, B. Experientia 1981, 37, 442-443.

2. Fusetani, N.; Matsunaga, S.; Konosu, S. Experientia 1981, 37, 680-681.

3. Okuda, R. K.; Klein, D.; Kinnel, R. B.; Li, M.; Scheuer, P. J. Pure Appl. Chem. 1982, 54, 1907-1914.

4. Li, M. K. W.; Scheuer, P. J. Tetrahedron Lett. 1984, 25, 587-590.

5. Li, M. K. W.; Scheuer, P. J. Tetrahedron Lett. 1984, 25, 2109-2110.

6. Li, M. K. W.; Scheuer, P. J. Tetrahedron Lett. 1984, 25, 4707-4708.

7. Sakemi, S.; Higa, T. Experientia 1987, 43, 624-625.

8. Tanaka, J.I.; Miki, H.; Higa, T. J. Nat. Prod. 1992, 55, 1522-1524.

9. Ochi, M.; Kataoka, K.; Tatsukawa, A.; Kotsuhi, H.; Shibata, K. Chem. Lett. 1993, 2003-2006.

10. Seo, Y.; Rho, J.-R.; Geum, N.; Yoon, J. B.; Shin, J. J. Nat. Prod. 1996, 59, 985-986.

11. Aknin, M.; Rudi, A.; Kashman Y.; Gaydou, E. M. J. Nat. Prod. 1998, 61, 1286-1287.

12. Howard, B. M.; Fenical, W. Tetrahedron Lett. 1978, 2453-2456.

13. Haagen-Smit, A. J. Fortschr. Chem. Org. Naturst. 1948, 5, 40-71.

14. Nozoe, T.; Ito, S. Fortschr. Chem. Org. Naturst. 1961, 19, 32-119.

15. Rodrìguez, A.D.; Boulanger, A. J. Nat. Prod. 1996, 59, 653-657.

16. Rodrìguez, A.D.; Boulanger, A. J. Nat. Prod. 1997, 60, 207-211.

17. Alpertunga, B.; Imre, S.; Cowe, H.; Cox, P. J.; Thomson, R. H. Tetrahedron Lett. 1983, 24, 4461-4462.

18. Wilsanand, V.; Wagh, A.B.; Bapuji, M. Indian J. Mar. Sci. 1999, 28, 280-284.

19. Wilsanand, V.; Wagh, A.B.; Bapuji, M. Microbios 2001, 104, 131-140.

20. Due to the easy degradation of compound $\mathbf{5}$ it is conceivable that the optical rotation value may be inaccurate. ${ }^{1} \mathrm{H}-$ NMR spectrum was also recorded in $\mathrm{CDCl}_{3}$ as reported in ref. 8 .

21. Compound 5: $\mathrm{R}_{f}=0.50$ ( $n$-hexane); $[\alpha]_{\mathrm{D}}^{25}=-14^{\circ}\left(\mathrm{c}=1.0 \mathrm{mg}, n\right.$-hexane); lit. [8] $[\alpha]_{\mathrm{D}}{ }^{20}=-91^{\circ}\left(\mathrm{CHCl}_{3}\right) ; \mathrm{APCIMS} \mathrm{m} / z$ 215.1440 (calculated for $\left.\mathrm{C}_{15} \mathrm{H}_{18} \mathrm{OH}^{+}: 215.1436\right)$; ${ }^{1} \mathrm{H}-\mathrm{NMR}\left(400 \mathrm{M} \mathrm{Hz}, \mathrm{C}_{6} \mathrm{D}_{6}\right): \delta 6.93(1 \mathrm{H}, \mathrm{bs}, \mathrm{H}-2), \delta 4.98(1 \mathrm{H}, \mathrm{bs}, \mathrm{H}-$ 11a), $\delta 4.90$ (1H, bs, H-11b), $\delta 3.59$ (1H, bd, J=17.8 Hz, H-9), $\delta 3.26$ (1H, m, H-4), $\delta 3.02$ (1H, d, J=17.8 Hz, H-9), $\delta$ $2.52(1 \mathrm{H}, \mathrm{dt}, J=3.42,3.42,15.7 \mathrm{~Hz}, \mathrm{H}-7 \mathrm{a}), \delta 2.38(2 \mathrm{H}, \mathrm{m}, \mathrm{H}-6), \delta 2.28(2 \mathrm{H}, \mathrm{m}, \mathrm{H}-4), \delta 2.24(1 \mathrm{H}, \mathrm{m}, \mathrm{H}-7 \mathrm{~b}), \delta 1.72(3 \mathrm{H}$, 
bs, $\left.\mathrm{H}_{3}-10\right), \delta 1.52$ (3H, bs, $\left.\mathrm{H}_{3}-12\right) .{ }^{13} \mathrm{C}-\mathrm{NMR}\left(\mathrm{C}_{6} \mathrm{D}_{6}\right): \delta 156.3$ (C-5, C), $\delta 149.2(\mathrm{C}-9 \mathrm{a}, \mathrm{C}), \delta 140.5$ (C-7a, C), $\delta 135.7$ (C2, CH), $\delta 124.5(\mathrm{C}-8, \mathrm{C}), \delta 121.1(\mathrm{C}-3, \mathrm{C}), \delta 119.3$ (C-3a, C), $\delta 105.6\left(\mathrm{C}-11, \mathrm{CH}_{2}\right), \delta 46.0(\mathrm{C}-4 \mathrm{a}, \mathrm{CH}), \delta 33.7(\mathrm{C}-9$, $\left.\mathrm{CH}_{2}\right), \delta 32.8\left(\mathrm{C}-4, \mathrm{CH}_{2}\right), \delta 30.2\left(\mathrm{C}-6, \mathrm{CH}_{2}\right), \delta 29.9\left(\mathrm{C}-7, \mathrm{CH}_{2}\right), \delta 21.3\left(\mathrm{C}-12, \mathrm{CH}_{3}\right), \delta 8.8\left(\mathrm{C}-10, \mathrm{CH}_{3}\right)$.

22. Compound 3: $\mathrm{R}_{f}=0.45$ ( $n$-hexane); $[\alpha]_{\mathrm{D}^{25}}=-2.8^{\circ}$ ( $\mathrm{c}=0.07, n$-hexane); APCIMS: $m / z 215.1431$ (calculated for $\left.\mathrm{C}_{15} \mathrm{H}_{18} \mathrm{OH}^{+}: 215.1436\right) ;{ }^{1} \mathrm{H}$ - and ${ }^{13} \mathrm{C}-\mathrm{NMR}$ data are given in Table 1.

23. Compound 4: $\mathrm{R}_{f}=0.40$ ( $n$-hexane); $[\alpha]_{\mathrm{D}}^{25}=-38.2^{\circ}(\mathrm{c}=0.07, n$-hexane); APCIMS: $m / z 213.1520$ (calculated for $\left.\mathrm{C}_{15} \mathrm{H}_{16} \mathrm{OH}^{+}: 213.1517\right) ;{ }^{1} \mathrm{H}$ - and ${ }^{13} \mathrm{C}-\mathrm{NMR}$ data are given in Table 1.

24. Fato, R.; Estornell, D.; Bernardo, S.; Pallotti, F.; Parenti-Castelli, G.; Lenaz, G. Biochemistry 1996, 35, 2705-2716.

25. Fontana, A.; Cimino, G.; Gavagnin M.; Gonzalez M.C.; Estronell, E.; J. Med. Chem. 2001, 44, 2362-2365.

Table 1 NMR Spectroscopic Data ${ }^{\mathrm{a}}\left(400 \mathrm{MHz}, \mathrm{C}_{6} \mathrm{D}_{6}\right.$ ) for compound (3) and compound (4)

\begin{tabular}{|c|c|c|c|c|}
\hline \multirow[b]{2}{*}{ Position } & \multicolumn{2}{|c|}{3} & \multicolumn{2}{|c|}{4} \\
\hline & $\delta_{\mathrm{C}}$ mult. & $\delta_{\mathrm{H}}(J$ in $\mathrm{Hz})$ & $\delta_{\mathrm{C}}$ mult. & $\delta_{\mathrm{H}}(J$ in $\mathrm{Hz})$ \\
\hline 2 & $136.0 \mathrm{CH}$ & $6.94 \mathrm{bs}$ & $137.3 \mathrm{CH}$ & 6.77 bs \\
\hline 3 & $121.8 \mathrm{qC}$ & - & $120.6 q C$ & - \\
\hline 3a & $120.0 q C$ & - & $119.5 q C$ & - \\
\hline \multirow[t]{2}{*}{4} & $29.8 \mathrm{CH}_{2}$ & $2.80 \mathrm{dd}(16.4,3.9)$ & $122.4 \mathrm{CH}$ & $6.75 \mathrm{~s}$ \\
\hline & & $2.39 \mathrm{dd}(16.4,3.1)$ & & \\
\hline $4 a$ & $45.9 \mathrm{CH}$ & $2.56 \mathrm{~m}$ & $133.2 q C$ & - \\
\hline 5 & $156.1 \mathrm{qC}$ & - & $144.1 \mathrm{qC}$ & - \\
\hline \multirow[t]{2}{*}{6} & $32.0 \mathrm{CH}_{2}$ & $2.28 \mathrm{~m}$ & $125.6 \mathrm{CH}$ & -6.02 bs \\
\hline & & $2.11 \mathrm{~m}$ & & \\
\hline \multirow[t]{2}{*}{7} & $28.6 \mathrm{CH}_{2}$ & $1.67 \mathrm{~m}$ & $125.6 \mathrm{CH}$ & -6.02 bs \\
\hline & & $1.32 \mathrm{~m}$ & & \\
\hline $7 a$ & $50.9 \mathrm{CH}$ & $2.35 \mathrm{~m}$ & $138.1 \mathrm{qC}$ & - \\
\hline 8 & $137.3 q C$ & - & $31.5 \mathrm{CH}$ & $2.83 \mathrm{~m}$ \\
\hline \multirow[t]{2}{*}{9} & $116.8 \mathrm{CH}$ & $6.33 \mathrm{bs}$ & $34.1 \mathrm{CH}_{2}$ & $2.82 \mathrm{dd}(16.4,2.9)$ \\
\hline & & & & $2.66 \mathrm{dd}(16.4,9.4)$ \\
\hline $9 a$ & $149.0 \mathrm{qC}$ & - & $158.1 \mathrm{qC}$ & - \\
\hline 10 & $7.8 \mathrm{CH}_{3}$ & $1.73 \mathrm{bs}$ & $7.4 \mathrm{CH}_{3}$ & $1.73 \mathrm{bs}$ \\
\hline \multirow[t]{2}{*}{11} & $105.6 \mathrm{CH}_{2}$ & $5.00 \mathrm{bs}$ & $12.2 \mathrm{CH}_{3}$ & $2.06 \mathrm{bs}$ \\
\hline & & 4.91 bs & & \\
\hline 12 & $22.2 \mathrm{CH}_{3}$ & $1.67 \mathrm{bs}$ & $19.8 \mathrm{CH}_{3}$ & $1.08 \mathrm{~d}(6.8)$ \\
\hline
\end{tabular}

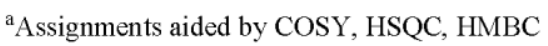<smiles>Cc1cc2occ(C)c2cc2c(C)ccc1-2</smiles>

1<smiles>CC1=CC=C2C1=Cc1c(C)coc1CC2C</smiles>

4<smiles>Cc1ccc(C(C)C)cc2c(C)ccc1-2</smiles>

2<smiles>C=C1CCC2=C(C)Cc3occ(C)c3CC12</smiles>

5<smiles>C=C1CC[C@H]2C(C)=Cc3occ(C)c3CC12</smiles>

3<smiles>C=C1Cc2occ(C)c2CC2C(=C)CCC12</smiles>

6 